NIM : 10200120160

KELAS : HTN - D

\title{
PARTAI POLITIK
}

Partai politik dibentuk untuk menjalankan kekuasaan politik baik ketika membentuk pemerintahan atau ketika partai politik sebagai oposisi di dalam pemerintahan. Partai politik diadakan tidak lain untuk mencapai kekuasaan baik dilembaga eksekutif maupun lembaga legislatif. Salah satu fungsi dari partai politik adalah sarana rekruitmen politik yang dilakukan melalui pemilu yang sudah lazim dilaksanakan di negara-negara demokratis untuk melahirkan pemimpin-pemimpin bangsa. Fungsi inilah yang dirasa belum maksimal karena pada proses pilkada serentak tahun 2015 ini ada beberapa daerah yang memiliki kandidat tunggal kepala daerah, bahkan daerah yang memiliki dua sampai tiga calon pun dikhawatirkan pada akhirnya akan memunculkan juga kandidat tunggal dikarenakan banyak yang tidak lolos verifikasi. Hal ini pada akhirnya akan berdampak pada dipertanyakannya nilai-nilai demokrasi yang berlaku di Indonesia dan kinerja partai politik dalam melahirkan kader-kader pemimpin bangsa.

\section{- Sejarah Lahirnya Partai Politik}

Partai politik pertama-tama lahir di negara-negara Eropa Barat. Dengan meluasnya gagasan bahwa rakyat merupakan faktor yang perlu diperhitungkan serta diikutsertakan dalam proses politik, maka partai politik telah lahir secara spontan dan berkembang menjadi penghubung antara rakyat di satu pihak dan pemerintah di pihak lain. Partai politik umumnya umumnya dianggap sebagai manifestasi dari suatu sistem politik yang sudah modern atau yang sedang dalam proses memodernisasikan diri. Maka dari itu, dewasa ini di negara- negara baru pun partai sudah menjadi lembaga politik yang biasa dijumpai. Di negara-negara yang menganut paham demokrasi, gagasan mengenai partisipasi rakyat mempunyai dasar ideologis bahwa rakyat berhak turut menentukan siapa-siapa yang akan menjadi pemimpin yang nantinya menentukan kebijaksanaan umum (public policy). Di negara-negara totaliter gagasan menganai partisipasi rakyat didasari pandangan elite politiknya bahwa rakyat perlu dibimbing dan dibina untuk mencapai stabilitas yang langgeng. Untuk mencapai tujuan itu, partai politik merupakan alat yang baik. Pada permulaan perkembangnnya di negara-negara Barat seperti Inggris dan Prancis kegiatan politik pada mulanya dipusatkan pada kelompok-kelompok politik dalam parlemen. 
Kegiatan ini mulanya bersifat elitist dan aristokrasis, mempertahan kepentingan kaum bangsawan terhadap tuntutan-tuntutan raja. Dengan meluasnya hak pilih, kegiatan politik juga berkembang di luar parlemen dengan terbentuknya panitia-panitia pemilihan yang mengatur pengumpulan suara para pendukungnya menjelang masa pemilihan umum. Oleh karena itu dirasa perlu memperoleh dukungan dari berbagai golongan masyarakat, kelompok-kelompok politik dalam parlemen lambat laun berusaha mengembangkan organisasi massa, dan dengan demikian terjalinlah suatu hubungan yang tetap antara kelompok-kelompok politik dalam parlemen dengan panitia-panitia pemilihan yang sepaham, dan lahirlah partai politik.partai semacam ini menekankan kemenangan dalam pemilihan umum dan dalam masa antara dua pemilihan umum biasanya kurang aktif. la bersifat patronage party (partai perlindungan) yang biasanya tidak memiliki disiplin partai yang ketat. Setelah kemerdekaan dicapai dan dengan meluasnya proses urbanisasi, komunikasi massa serta pendidikan umum, maka bertambah kuatlah kecenderungan untuk berpartsipasi daam proses politik melalui partai.

\section{- Definisi Partai Politik}

Partai politik adalah suatu kelompok yang terorganisir yang anggota-anggotanya mempunyai orientasi, nilai-nilai dan cita-cita yang sama. Tujuan kelompok ini ialah untuk memperoleh kekuasaan politik biasanya dengan cara konstitusionil untuk melaksanakan kebijaksanaan-kebijaksanaan mereka.

Carl J. Friedrich mendefinisikan partai politik adalah "sekelompok manusia yang terorganisir secara stabil dengan tujuan merebut atau mempertahankan penguasaan terhadap pemerintahan bagi pimpinan partainya dan, berdasarkan penguasaan ini memberikan kepada anggita partainya kemanfaatan yang bersifat idiil maupun materiil" (A political party is a group of human beings, stably organized with the objective of giving to members of the party, through such control ideal and material benefits and advantages).

\section{- Fungsi Partai Politik}

Dalam negara demokratis partai politik menyelenggarakan beberapa fungsi:

1. Partai sebagai sarana komunikasi politik. Dalam hal ini partai politik juga berfungsi untuk memperbincangkan dan menyebarluaskan rencana-rencana dan kebijakankebijakan pemerintah. Partai politik memainkan peran sebagai penghubung antara yang memerintah dan yang diperintah. Partai politik merumuskan usulan-usulan atau mengagregasikan kebijakan yang bertumpu pada aspirasi dari masyarakat. Kemudian rumusan tersebut diartikulasikan kepada pemerintah agar dapat dijadikan sebagai sebuah kebijakan. Proses ini menunjukan bahwa komunikasi antar pemerintah dengan masyarakat dapar dijembatani oleh partai politik. Dan bagi partai politik mengartikulasikan aspirasi rakyat merupakan suatu kewajiban yang tidak dapat dielakkan, terutama bila partai politik tersebut ingin tetap eksis dalam kancah politik nasional. Oleh sebab itu partai politi sering disebut sebagai broker (perantara) dan alat pendengar, sedangkan warga masyarakat sebagai pengeras suara. 
2. Sebagai Sarana Sosialisasi Politik Partai politik menjadi penghubung yang mensosialisasikan nilai-nilai politik generasi yang satu ke generasi yang lain. Pelaksanaan fungsi sosialisasi ini di lakukan melalui berbagai cara yaitu media massa, ceramah-ceramah, penerangan, kursus kader, penataran, dsb. Fungsi lain dari sosialisasi politik adalah upaya menciptakan citra (image) bahwa ia memperjuangkan kepentingan umum.

3. Sebagai Sarana Rekruitment Politik Dimana partai politik berkewajiban untuk melakukan seleksi dan rekruitmen dalam rangka mengisi posisi dan jabatan politik tertentu. Dengan adanya rekruitmen politik maka dimungkinkan terjadinya rotasi calon mobilitas politik. Tanpa rotasi dan mobilitas politik pada sebuah sistem politik, maka akan muncul diktatorisme dan stagnasi politik dalam sistem tersebut. Rekruitmen politik menjamin kontinuitas dan kelestarian partai, sekaligus merupakan salah satu cara untuk menjaring dan melatih calon-calon pemimpin.

4. Sebagai Sarana Pengatur Konflik (Conflict Management) Partai politik dapat menjadi penghubung psikologis dan organisasional antara warga negara dengan pemerintahnya. Selain itu, partai juga melakukan konsolidasi dan artikulasi tuntutantuntutan yang beragam yang berkembang di berbagai kelompok masyarakat.

\section{PEMILIHAN UMUM}

Pemilu adalah wujud nyata demokrasi prosedural, meskipun demokrasi tidak sama dengan pemilihan umum, namun pemilihan umum merupakan salah satu aspek demokrasi yang sangat penting yang juga harus diselenggarakan secara demokratis. Oleh karena itu, lazimnya di negaranegara yang menamakan diri sebagai negara demokrasi mentradisikan Pemilu untuk memilih pejabat-pejabat publik di bidang legislatif dan eksekutif baik di pusat maupun daerah. Veri Junaidi menyatakan pemilu dan demokrasi merupakan suatu "qonditio sine qua non", the one can not exist without the others. Dalam arti bahwa pemilu dimaknai sebagai prosedur untuk mencapai demokrasi atau merupakan prosedur untuk memindahkan kedaulatan rakyat kepada kandidat tertentu untuk menduduki jabatan-jabatan politik. Jadi penyelenggaraan pemilu dalam suatu negara merupakan penyaluran hak-hak politik warga negara, mewujudkan kedaulatan rakyat, serta sarana untuk menyukseskan peralihan pemerintahan berdasarkan hukum. Selayaknya negaranegara modern, Indonesia berupaya untuk mewujudkan paham kedaulatan rakyat dan demokrasi melalui penyelenggaraan pemilihan umum. Dengan adanya pemilihan umum maka rakyat akan dimungkinkan untuk turut serta menentukan arah pemerintahan suatu negara. Aspirasi warga negara dalam pemilihan umum tersebut disalurkan melalui wakil rakyat terpilih, yang diberikan kewenangan oleh warga negara untuk mengawasi jalannya pemerintahan. Pada awal masa kemerdekaan, pemilihan umum diselenggarakan untuk menentukan wakil rakyat yang duduk pada lembaga perwakilan rakyat. Namun pada tahun 2004 era pemilihan umum di Indonesia tidak hanya memilih wakil rakyat melainkan 
memulai sejarah baru pemilihan umum presiden secara langsung. Pemilihan umum tahun 2004 inilah dapat disebut sebagai awal mula perubahan sistem pemilu mekanis di Indonesia dari sistem mekanis tertutup ke dalam sistem mekanis terbuka. Hal ini karena tiap-tiap warga negara memiliki hak langsung untuk memilih wakil rakyat dan presidennya. Partai politik dalam hal ini tidak lagi dapat mendistribusikan suara yang diperoleh secara proporsional sesuai nomor urut calon wakil rakyat, melainkan sesuai dengan jumlah suara yang diperoleh perorangan calon wakil rakyat. Meskipun demikian sistem pemilu mekanis terbuka ini tidak terlepas dari berbagai variasi. Oleh karena itulah akan dilakukan kajian mengenai berbagai variasi mengenai implementasi sistem mekanis terbuka tersebut dalam pemilu di Indonesia.

Dalam pelaksanaan pemilihan umum asas - asas yang digunakan diantaranya sebagai berikut :

A. Langsung, berarti masyarakat sebagai pemilih memiliki hak untuk memilih secara langsung dalam pemilihan umum sesuai dengan keinginan diri sendiri tanpa ada perantara

B. Umum, berarti pemilihan umum berlaku untuk seluruh warga negara yang memenuhi persyaratan, tanpa membeda-bedakan agama, suku, ras, jenis kelamin, golongan, pekerjaan, kedaerahan, dan status sosial yang lain.

C. Bebas, berarti seluruh warga negara yang memenuhi persyaratan sebagai pemilih pada pemilihan umum, bebas menentukan siapa saja yang akan dicoblos untuk membawa aspirasinya tanpa ada tekanan dan paksaan dari siapa pun.

D. Rahasia, berarti dalam menentukan pilihannya, pemilih dijamin kerahasiaan pilihannya. Pemilih memberikan suaranya pada surat 23 suara dengan tidak dapat diketahui oleh orang lain kepada siapa pun suaranya diberikan.

E. Jujur, berarti semua pihak yang terkait dengan pemilu harus bertindak dan juga bersikap jujur sesuai dengan peraturan perundang-undangan yang berlaku.

F. Adil berarti dalam pelaksanaan pemilu, setiap pemilih dan peserta pemilihan umum mendapat perlakuan yang sama, serta bebas dari kecurangan pihak manapun.

\section{- TUJUAN PEMILU}

Pemilihan Umum Menurut Prihatmoko (2003:19) pemilu dalam pelaksanaanya memiliki tiga tujuan yakni:

1) Sebagai mekanisme untuk menyeleksi para pemimpin pemerintahan dan alternatif kebijakan umum (public policy). 
2) Pemilu sebagai pemindahan konflik kepentingan dari masyarakat kepada badan badan perwakilan rakyat melalui wakil wakil yang terpilihatau partai yang memenangkan kursi sehingga integrasi masyarakat tetap terjamin.

3) Pemilu sebagai sarana memobilisasi, menggerakan atau menggalang dukungan rakyat terhadap Negara dan pemerintahan dengan jalan ikut serta dalam proses politik.

Selanjutnya tujuan pemilu dalam pelaksanaanya berdasarkan Undang-Undang Nomor 8 tahun 2012 pasal 3 yakni pemilu diselenggarakan untuk memilih anggota DPR, DPRD Provinsi dan DPRD Kabupaten/Kota dalam Negara Kesatuan Republik Indonesia yang berdasarkan Pancasila dan Undang-Undang Dasar Negara Republik Indonesia tahun 1945.

\section{- Pemilihan Umum Raya Model Partai Politik}

Dewasa ini sangat jarang menemukan Partai Politik untuk menentukan calon yang akan di usung untuk menjadi Calon Presiden melalui sistem pemilihan secara langsung, yang sering kita temui yaitu Ketua Partai Politik atau atas putusan Ketua Partai politik tersebut. Namun ada salah satu Partai Politik yang masih menggunakan sistem pemilihan secara langsung oleh kader-kader Partai Politik tersebut yaitu Partai Kesejahteraan Sosial yang bernama Pemilihan Umum Raya atau PEMIRA Melalui PEMIRA, calon dari luar partaipun bisa ikut, jika memang parpol yang bersangkutan membuka peluang itu. "Dengan demikian keinginan mereka yang non parpol bisa menjadi capres terpenuhi dan tetap sesuai Konstitusi," Pemira PKS diikuti oleh kader yang memiliki kartu anggota, bukan sekadar pendukung atau simpatisan. Dalam pemilihan, setiap pemilik suara harus memilih 5 dari 22 tokoh PKS yang dicalonkan, bukan memilih satu nama seperti pemilihan biasa. Karena itu, pemenang Pemira ini juga bukan satu. Panitia nanti akan mengambil lima kandidat. Kelima nama ini kemudian diserahkan ke Majelis Syoru untuk dipilih satu orang yang bakal diusung. "Yang menetapkan siapa yang menjadi capres adalah Majelis Syuro". Seharusnya semua Partai Politik bisa menerapkan sistem Pemilihan Umum 36 Raya ini. Karena dengan sistem ini, setiap capres yang nantinya di usung setiap Partai Politik itu adalah orang yang memang benar-benar pantas dan sudah teruji karena sudah melalui beberapa tahapan yang obyektif untuk maju dalam pemilihan presiden

\section{FUNGSI SISTEM PEMILIHAN UMUM ANGGOTA DPR DAN DPRD}

1. Sebagai prosedur dan mekanis mekonversi suara pemilih (votes) menjadi kursi (seats) penyelenggara negara lembaga legislatif dan/ atau lembaga eksekutif baik pada tingkat nasional maupun lokal. Prosedur dan mekanisme seperti inilah yang biasa disebut proses penyelenggaan tahapanPemilu.

2. Sebagai instrumen untuk membangun sistem politik demokrasi, yaitu melalui konsekuensi setiap unsursis tempemilihan umum terhadap berbagai aspek sistem politik demokrasi. 


\section{- SISTEM SISTEM PEMILU}

Didalam pelaksanaan pemilu ada beberapa sistem yang harus diketahui oleh masyarakat agar mereka memahami jika indonesia memiliki 3 sistem pemilu yang saling berhubungan. Berikut adalah sistem pemilu

A. "Sistem pemilu umum jenis distrik adalah pemilihan umum yang mengandalkan daerah penduduk dan bukan dilihat dari berapa jumlah penduduk yang ada. Walaupun banyak calon pemimpin yang ditawarkan ketika dalam berkampanye namun ketika pemilihan umum berlangsung hanya satu yang akan menjadi pemenangnya.Jenis sistemnya :

1. Mayoritas multak (First Past The Post/FPTP)

2. Suara alternatif (Alternative Vote/AV)

3. Suara blok (Block Vote/BV)

4. Sistem putaran dua (Two Round System/TRS)

B. "Pemilihan kombinasi adalah gabungan antara sistem pemilu yang menggunakan sistem pemilu proporsional dan distrik. contohnya sebagian anggota dari parlemen negara dipilih dengan menggunakan sistem proporsional dan yang setengah lainnya menjalani pemilihan dalam sistem distrik Jenis sistemnya":

1. Suara non dipindahtangankan tunggal (Single Non Transferable Vote/SNTV)

2. Sistem paralel (Parallel system)

3. Suara terbatas (Limited vote)

4. Suara kumulatif (Cumulative vote) 


\section{REFERENSI}

https://media.neliti.com/media/publications/132812-ID-peran-partai-politik-dalammensukseskan.pdf

http://repository.umy.ac.id/bitstream/handle/123456789/16892/F.\%20BAB\%20ll.pdf?seque nce $=6 \&$ isAllowed $=y$

https://core.ac.uk/download/pdf/231316145.pdf

http://repository.unpas.ac.id/13193/5/BAB\%20ll.pdf 